\title{
Leaf litter hides post-dispersed seeds from invasive alien removers in a sclerophyll forest in central Chile
}

\author{
Luis Cáceres-Polgrossi (Cáceres-Polgrossi, Luis) ${ }^{1,2^{*}}$, Alvaro Promis (Promis, Alvaro)1, Alvaro G. Gutiérrez (Gutiérrez, \\ Alvaro G. $)^{2}$ \\ ${ }^{\prime}$ Departamento de Silvicultura y Conservación de la Naturaleza, Facultad de Ciencias Forestales y de la Conservación de la Naturaleza, Universidad de \\ Chile, Chile. Santa Rosa 11315, La Pintana, Santiago, Chile. ${ }^{2}$ Departamento de Ciencias Ambientales y Recursos Naturales Renovables, Facultad de \\ Ciencias Agronómicas, Universidad de Chile, Chile. Santa Rosa 11315, La Pintana, Santiago, Chile.
}

\begin{abstract}
Aim of study: Seed removal may be a determining filter for regeneration. Factors such as leaf litter, tree cover and seed density affect seed removal. This aims to assess three aspects involving on post dispersal seed removal of four woody species (Lithraea caustica, Maytenus boaria, Quillaja saponaria and Retanilla ephedra) of a sclerophyll forest.

Area of study: Andean Mediterranean sclerophyll forest of Quillaja saponaria and Lithraea caustica located in the Río de Los Cipreses National Reserve, Chile.

Material and methods: Seven experimental plots were set up, in which seeds were offered in an experiment with variations in leaf litter, tree cover and seed density. Generalized Linear Mixed Models (GLMM) were used for the statistical analysis. Camera traps were installed to identify the seed removers.

Main results: $Q$. saponaria seeds were more removed than the seeds of the other species $(0.84$, observed mean). Whereas that $M$. boaria and $R$. ephedra did not show significant differences on the removal of their seeds ( 0.77 and 0.67 respectively), both were more removed than L. caustica (0.59). The removal of M. boaria, Q. saponaria and R. ephedra seeds was lower in the presence of leaf litter. No factor influenced the removal of L. caustica seeds. Seed removers were identified as invasive alien species such as Rattus sp. and Oryctolagus cuniculus and native species such as Lycalopex culpaeus.

Research highlights: Three woody species of this forest suffer severe seed removal by invasive alien fauna with major implications for the resilience of these forests. The coverage of leaf litter is key to hide away the seeds, increasing survival and could promote germination.

Keywords: invasive alien fauna; Mediterranean forest; sclerophyll forest; seed removal factors.

Authors' contributions: Conceived and designed the experiment: AP. Performed the experiment: LCP and AP. Analyzed the data: LCP. Funding acquisition and project administration: AP. Wrote the manuscript: LCP, AP, AGG. All the authors approved the final version of the manuscript.

Citation: Cáceres-Polgrossi, L., Promis, A.; Gutiérrez, A.G. (2020). Leaf litter hides post-dispersed seeds from invasive alien removers in a sclerophyll forest in central Chile. Forest Systems, Volume 29, Issue 3, e022. https://doi.org/10.5424/fs/2020293-16845.

Supplementary material: Tables S1 and S2, and Figure S1 accompany the paper on FS's website.

Received: 14 Apr 2020. Accepted: 29 Dec 2020.

Copyright $(92020$ INIA. This is an open access article distributed under the terms of the Creative Commons Attribution 4.0 International (CC-by 4.0) License.

Funding: This study was funded by the Fondo Científico del Alto Cachapoal de Pacific Hydro.

Competing interests: The authors have declared that no competing interests exist.

Correspondence should be addressed to Luis Cáceres-Polgrossi: cac.polgrossi@gmail.com
\end{abstract}

\section{Introduction}

The Central Chile forest is part of the five regions in the world with Mediterranean ecosystems. These regions hold almost $20 \%$ of the world's flora (Cowling et al., 1996), have a high level of endemism (Naveh \& Wittaker, 1979; Arroyo \& Uslar, 1993; Arroyo et al., 1993; Cowling et al., 1996) and cover less than 5\% of the world's surface (Cowling et al., 1996). Also, these regions are recognized as biodiversity hotspots due those important biodiversity characteristic and the large number of threatened species by anthropogenic impacts (Myers et al., 2000).
The forest in Central Chile is considered the area that has received the most severe anthropogenic disturbances in South America (Salazar et al., 2015) and in the country (Rundel, 1998), causing deep transformations to the landscape (Elizalde, 1970; Schulz et al., 2011) and putting this region's remaining biodiversity at severe and increasing risk (Hobbs et al., 1995; Armesto et al., 1998). In the past, the forest was dense and biologically diverse (Aronson et al., 1998). Thus, today the forest is heavily fragmented and it has been suggested it has problems with its regeneration process, with little recuperative capacity (Jiménez \& Armesto, 1992; Schulz et al., 2010). 
Inside of plant communities, species have different requirements and responses at any stage in the regeneration process (Grubb, 1977). For the case of some species in a sclerophyll forest, one of the main forest types in Central Chile (Armesto et al., 2007; Salazar et al., 2015), it has been suggested that the transition from seed to seedling could be one of the key processes on the recruitment of tree species (Simonetti, 1983a; Bustamante, 1995). Specifically, seed removal may be a crucial filter for the recruitment of some species if these seeds are predated (Bustamante, 1995), dispersed to sites without the environmental conditions for their germination and establishment (Del Pozo et al., 1989; Bustamante et al., 1992; León-Lobos \& Arroyo, 1994) or if these do not resist the mastication and passage through the animal's digestive tract (Castro et al., 1994; Castro et al., 2008).

However, it has been suggested that factors like leaf litter, seed density and tree cover may affect the removal of these dispersed seeds and therefore species recruitment (Forget, 1992; Forget, 1993; Myster \& Pickett, 1993; Bustamante \& Vásquez, 1995; Cintra, 1997; Dalling, 2002, Yu et al., 2015; Dudenhöffer et al., 2016). For example, Janzen (1970) and Connell (1971) suggested that density dependent seed removers prefers areas with high seed densities becoming this areas in less safe to the species regeneration. Cintra (1997) suggested that the presence or not of leaf litter can influence the time and energy they invest in the search for seeds due to the difficulty to detect the seeds that are not visible (Cintra, 1997). Finally, Díaz et al. (1999) reported that areas with tree cover are safe areas for seed removers due the less visibility for to be predated. Nevertheless, how seed density, the presence of leaf litter and tree cover influences postdispersal seed removal in a sclerophyll forest is scarcely understood (Bustamante \& Vásquez, 1995).

On the other hand, it is highly known the existence of invasive alien species inhabiting the sclerophyll forest and different effects we can found in the literature about seed removal by invasive alien species. For example, Castro et al. (2008) suggested that Oryctolagus cuniculus are dispersing seeds of Lithraea caustica. On the contrary, Barceló \& Simonetti (2020) have suggested that Rattus rattus are predating seeds of Gomortega keule, endangered tree species of Central Chile. Thus, researches highlighting the potential negative effects of seed removal by invasive alien species are also scarce.

The objective of this study were to assess seed removal after dispersal from four woody species of a sclerophyll forest, to assess the influence of the factors leaf litter, seed density and tree cover and to identify seed removers with the motivation to know if these ecological interactions are contributing to the recruitment problems on the main species of this forest. To do so, the following questions were asked: How many seeds can be removed after dispersal? Could seed removal be an important filter for the recruitment of these species? How do the study factors affect seed removal? Which fauna are predator-dispersers of these seeds?

\section{Material and Methods}

\section{Study area}

The experiment was conducted in the Río de Los Cipreses National Reserve (Fig. 1; 34 ${ }^{\circ} 15^{\prime} 56.55^{\prime \prime}$; $70^{\circ} 27^{\prime} 56.97 \mathrm{\prime W}$ ). The reserve is located in the Andes mountains at a height that ranges from 900 to 3500 m.a.s.l. There are different plant associations at this altitudinal gradient, with the sclerophyll forest being predominant. Generally, the soils at the reserve are lithosol and to a lesser extent alluvial and colluvial soils. The climate is Mediterranean with an annual average precipitation of $1200 \mathrm{~mm}$, which occurs particularly in winter. The area has a dry period of between 3 and 4 months. The annual average temperature is $5.9^{\circ} \mathrm{C}$ (Uribe et al., 2012).

\section{Seed species features}

This study was realized between March and September 2015. Fruits and seeds were collected from Quillaja saponaria Molina (Quillajaceae), Lithraea caustica (Molina) Hook. \& Arn. (Anacardiaceae), Maytenus boaria (Hook. f.) Urb. (Celastraceae) and Retanilla ephedra (Vent.) Brongn. (Rhamnaceae) between March and April 2015. These trees and shrub ( $R$. ephedra) are typical species of the Andean Mediterranean sclerophyll forest dominated by $Q$. saponaria and L. caustica (Luebert \& Pliscoff, 2017). Approximately 6,500 seeds were collected, stored for their conservation in dry, cool containers until being offered to the fauna.

As we can see, in general the seeds are small and light (Table 1). Seed as L. caustica and R. ephedra are heavier than the others and its dispersal mechanism are barochory-endozoochory and barochory respectively. Whereas Lycalopex culpaeus and O. cuniculus have been described as dispersers for L. caustica (Medan \& Aagesen 1995; Catro et al., 2008; Morales-Paredes et al., 2015), M. boaria seeds are dispersed by Colorhamphus parvirostris, by Xolmis pyrope and by Anairetes parulus (Reid \& Armesto, 2011). The lightest seed of this study is a winged seed of $Q$. saponaria and its dispersal mechanism is meteoranemochory (Table 1).

After exploring and checking the area of occurrence of the sclerophyll forest in the Río de Los Cipreses National Reserve, seven experimental plots were set up with similar slope (between 3 and $8 \%$ ), altitude (1100 to 1200 m.a.s.l.) and contiguous areas with and without tree cover (Fig. 1). 


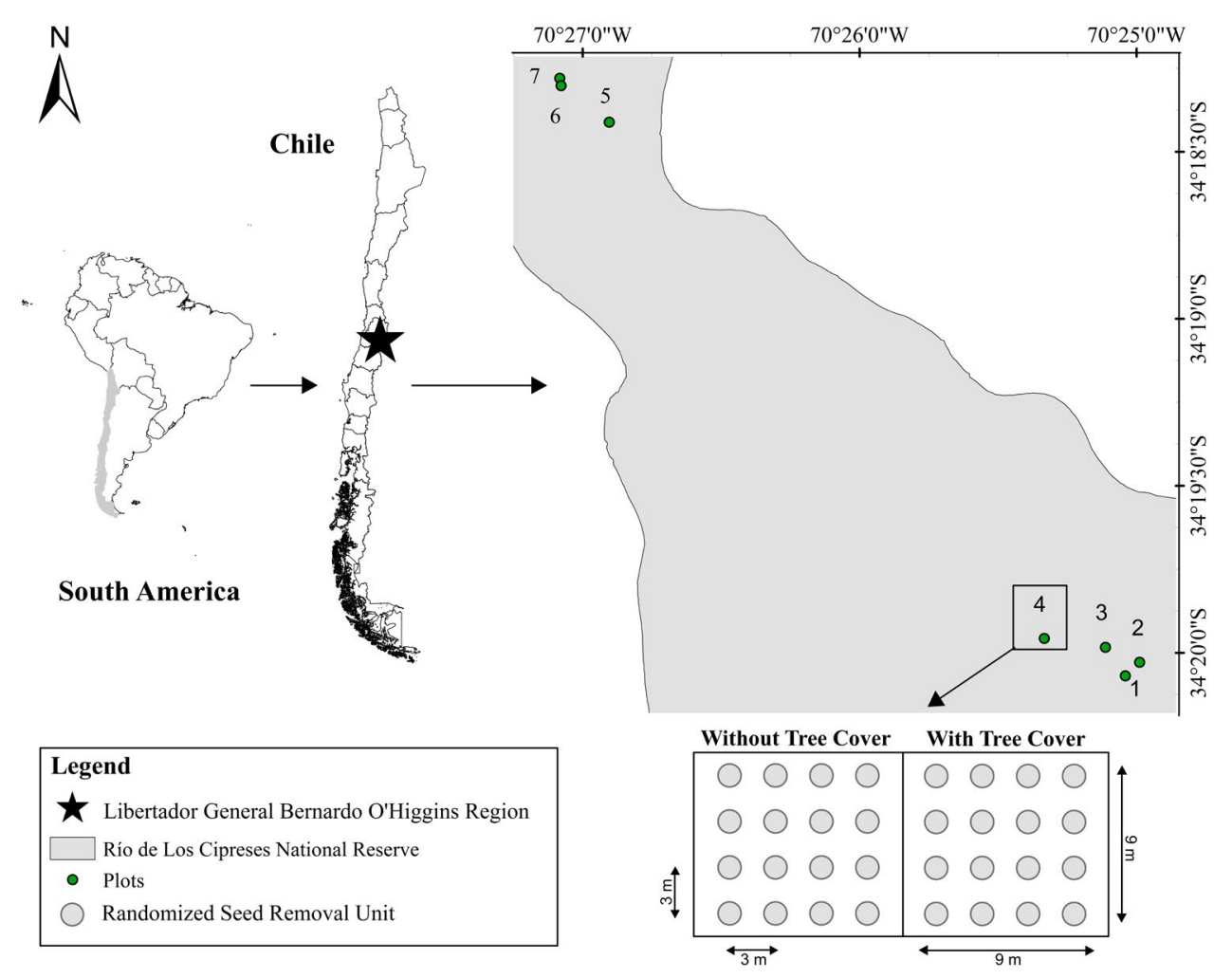

Figure 1. Study area and experimental design located at the Río de Los Cipreses National Reserve.

\section{Experimental desing}

On each experimental plot 224 seed removal units (SRUs) were installed after dispersal with their respective treatments (Fig. 1). The SRUs followed recommendations described by Herrera et al. (1994), Alcántara et al. (2000), García et al. (2005) and Jaña (2012). The SRUs were transparent and odorless plastic containers, $13 \mathrm{~cm}$ in diameter and five $\mathrm{cm}$ deep $\left(102.1 \mathrm{~cm}^{3}\right)$. These dimensions were due to the small size of the seeds of the species being studied $(<12 \mathrm{~mm})$. The SRUs were fixed to the ground with $3 \mathrm{~cm}$ nails. Holes were made in the lower part of SRUs, which were filled with $3 \mathrm{~cm}$ of stones and earth from the sector, leaving the seeds $2 \mathrm{~cm}$ from the upper edge of the container. Holes facilitate water infiltration in the event of possible precipitation, and the edge above the seeds avoids their loss due to overspill or wind. Seeds of M. boaria, L. caustica and R. ephedra were marked with a gray permanent and odorless marker (ZIG marker brand; model PS-220/5V) for recognition in case other seeds were accidentally added to the SRU. The seeds of Q. saponaria (winged seeds) were stuck with odorless, colorless glue on a mesh placed over the filling to avoid loss by wind.

SRUs were arranged in a $2 \times 2 \times 2$ completely randomized factorial experiment, with seven replicates (experimental plots) per treatment for each species (Fig. 1). Treatments consisted of combination of two levels of tree cover (SRUs without tree cover and with tree cover), two levels of leaf litter cover (SRUs without leaf litter and with seeds covered by leaf litter) and two levels of seed density (low density with five seeds in each SRUs

Table 1. Seed species features. Seed weight, length and width were calculated with the mean of $N=100$ seeds. Reported fruiting period and dispersal mechanism obtained from ${ }^{1}$ Morales-Paredes et al., (2015), ${ }^{2}$ Reid \& Armesto (2011), ${ }^{3}$ Montenegro et al. (1989), ${ }^{4}$ Velazco et al., 2018, 5 Medan \& Arce (1999)

\begin{tabular}{lcccccc}
\hline \multicolumn{1}{c}{ Species } & $\begin{array}{c}\text { Fruit } \\
\text { type }\end{array}$ & $\begin{array}{c}\text { Seed } \\
\text { weight }(\mathbf{g})\end{array}$ & $\begin{array}{c}\text { Seed } \\
\text { length }(\mathbf{c m})\end{array}$ & $\begin{array}{c}\text { Seed } \\
\text { width }(\mathbf{c m})\end{array}$ & $\begin{array}{c}\text { Reported } \\
\text { fruiting period }\end{array}$ & Reported dispersal mechanism $^{\text {Rutica }}$ \\
\hline Lithraea caustica & Drupe & 0.094 & 5.8631 & 3.4372 & Feb-Apr & Barochory; Endozoochory $^{1}$ \\
Maytenus boaria & Capsule & 0.022 & 4.6116 & 2.4867 & Feb-May & Endozoochory $^{2}$ \\
Quillaja saponaria & Capsule & 0.007 & 12.1351 & 0.907 & Jan-Mar & \\
Retanilla ephedra & Drupe & 0.064 & 6.8533 & 3.1505 & Oct-Jan $^{5}$ & Anemochory $^{4}$ \\
\hline
\end{tabular}


and high density with 50 seeds). Thus, each experimental plot consisted on two $4 \times 4$ grids (the first one without tree cover and the second one with tree cover) where we placed each SRU with leaf litter treatments and seed density treatments (Fig. 1).

The monitoring took place from April to September 2015. The SRUs were revisited on five separate occasions (approximately once a month). The monitoring involved making a count of the seeds present in the SRUs, without replenishment, to determine the number of seeds removed. During each of the visits, the number of seeds removed was calculated as the difference between the initial quantity of seeds placed on each removal unit (50 seeds or 5 seeds, according to the seed density).

\section{Identification of seed removers after dispersal}

The seed removers after dispersal were identified by installing four Bushnell camera traps with motion sensors (Trophy Cam HD). The cameras were installed in conditions with and without tree cover in two sectors of the study area in order to visualize possible predator differences between the two covers. Four SRUs were placed in front of the camera traps, offering seeds from each species being studied. The four camera traps were programmed so that they remained active all day, taking photographs at three-second intervals whenever they perceived movement. The camera traps were installed in June and worked until September. Later, the photographs were reviewed and selected those that showed animals taking seeds from the removal units. Descriptive statistics were used to analyze both the predator sightings as well as the species whose seed were removed. The rodents in the photographs were recognized at genus level. Other mammals were recognized at species level.

\section{Statistical analysis}

We conducted two analyses to detect significant differences ( $p>0.05)$ among species and factors on seeds removed. We used the complete data set to fitted two Ge- neralized Linear Mixed Model (GLMM) with a binomial distribution given the nature of the response variable (seeds removed or not; "rem" and "1-rem", Formula 1 and 2). Due our nested experimental design, date and plot were set as random effects to include plot specific effects and to take into account for temporal pseudoreplication (Model 1, Eq. 1 and Model 2, Eq. 2). With the "Ime4" package for GLMM in R Software (Bates et al., 2015; R Core Team, 2019), the first analysis was set with species ("spp") as a factor plus random effects factors (Model 1, Eq. 1).

$($ rem, $1-$ rem $) \sim \operatorname{spp}+(1 \mid$ date $)+(1 \mid$ plot $) \quad$ Eq. 1

The second analysis was set with the seeds removed per each specie ("rem") resulted at the end as the response variable. We set as factors the tree cover (TC), leaf litter cover (LL) density (D) and its interactions plus random effects factors (Model 2, Eq. 2).

$($ rem, $1-$ rem $) \sim \mathrm{LL}+\mathrm{D}+\mathrm{TC}+(\mathrm{LL}: \mathrm{D}: \mathrm{TC})+$ $(\mathrm{LL}: \mathrm{TC})+(\mathrm{LL}: \mathrm{D})+(\mathrm{D}: \mathrm{TC})+(1 \mid$ date $)+$ ( $1 \mid$ plot )

Eq. 2

We applied on both models the analysis of deviance for GLMM to detect significant differences with "car" package in R Software (Fox \& Weisberg, 2019; R Core Team, 2019), "Ismeans" package for post hoc analysis in R Software (Lenth, 2016; R Core Team, 2019) and "multcomp" packages in R Software for pairwise comparisons of least-squares means (Westfall et al., 1999; R Core Team, 2019).

\section{Results}

\section{Identification of seed removers}

Thirty photographs were obtained from the camera traps, where the main seed removers were identified: individuals of $O$. cuniculus (Fig. 2a), rodents of the genus Rattus sp. (Fig. 2b) and individuals of L. culpaeus (Fig. 2c). On site, seeds removed by $O$. cuniculus and

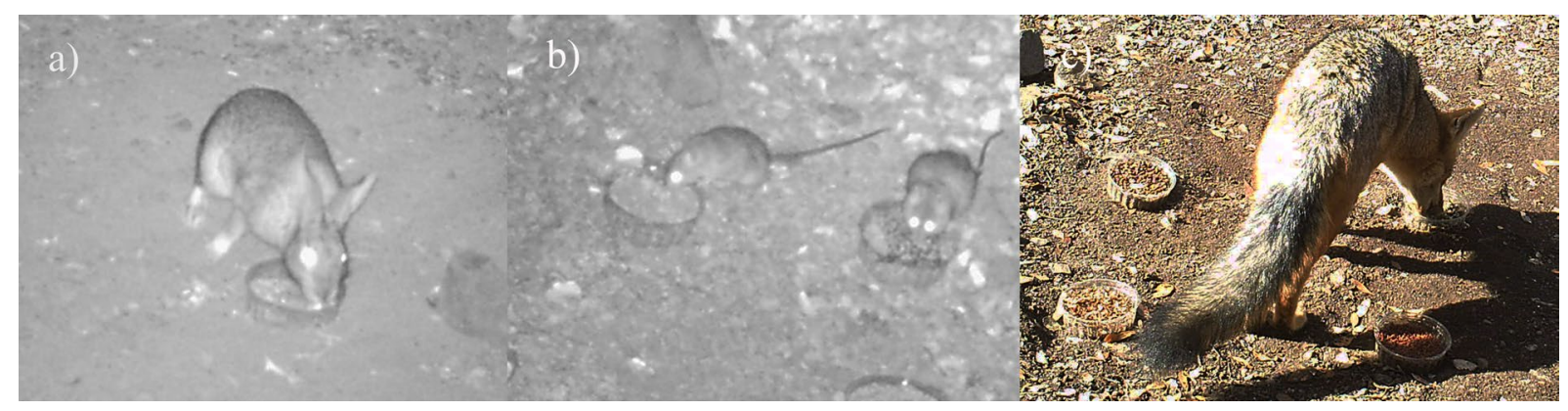

Figure 2. Typical fauna found removing seeds from the removal units: a) Oryctolagus cuniculus, b) Rattus $s p$. and c) Lycalopex culpaeus. 
individuals of Rattus $s p$. was confirmed, as remains of seeds nibbled by these individuals were found in the removal units.

$73 \%$ of the photographs that were taken at sites with tree cover showed rodents of the genus Rattus removing the seeds offered, $18 \%$ showed individuals of $O$. cuniculus and $9 \%$ L. culpaeus (Table 2). In sites without tree cover, $69 \%$ of the photographs showed individuals of $O$. cuniculus removing the seeds offered and $31 \%$ rodents of the genus Rattus (Table 2).

The SRUs that contained M. boaria seeds were preferred by individuals of $O$. cuniculus (Table 3 ) and those that contained $R$. ephedra seeds by rodents of the genus Rattus. L. culpaeus was detected removing only L. causti$c a$ seeds. The least visited SRUs by both $O$. cuniculus and rodents of the genus Rattus were those that contained $Q$. saponaria seeds (Table 3 ).

\section{Post-dispersed seeds removed of each species}

In general, seeds of the four species were located and removed from SRUs since the first monitoring (Fig. 3a). The greatest proportion of seeds removed in the first monitoring was, on average, from $R$. ephedra ( 0.52 of seeds removed). The seeds removed for each specie increased gradually towards the end of the monitoring (day 185, Fig. $3 a)$. In general, our first analysis showed significant differences among species on post-dispersed seeds removed ( $\mathrm{p}$ $<0.001$; see Table S1 [suppl.] for the GLMM summary). After, the comparisons of means showed that the removal

Table 2. Average percentage of photographs with seed removers removing seeds offered at sites with and without tree cover

\begin{tabular}{lcc}
\hline \multicolumn{1}{c}{ Species } & $\begin{array}{c}\text { Sites with } \\
\text { Tree Cover }\end{array}$ & $\begin{array}{c}\text { Sites without } \\
\text { Tree Cover }\end{array}$ \\
\hline Rattus sp. & $73 \%$ & $31 \%$ \\
Oryctolagus cuniculus & $18 \%$ & $69 \%$ \\
Lycalopex culpaeus & $9 \%$ & $0 \%$ \\
Total & $100 \%$ & $100 \%$ \\
\hline
\end{tabular}

proportion of $Q$. saponaria seeds $(0.84 \pm 0.04$, observed mean \pm standard error respectively) was significantly greater than the seeds removed proportion of M. boaria $(0.77$ $\pm 0.04, \mathrm{p}<0.002)$, R. ephedra $(0.67 \pm 0.05, \mathrm{p}<0.030)$ and L. caustica $(0.59 \pm 0.04, \mathrm{p}<0.001$, Fig. $3 \mathrm{~b})$. In contrast, the removal proportion of $R$. ephedra seeds did not show significant differences with $M$. boaria $(\mathrm{p}>0.830)$ and it was significantly greater than the removal proportion of $L$. caustica seeds $(\mathrm{p}<0.010)$. Also, the removal proportion of $M$. boaria was significantly higher than these for $L$. caustica $(\mathrm{p}<0.006)$. Finally, the seeds removed proportion of L. caustica was statistically lower than the seeds removed proportion of the other three species (Fig. 3b).

\section{Factors influencing seeds removed on each species}

The analysis of deviance applied to the Model 2 showed that seeds removed was significantly higher without leaf litter than those seeds covered with leaf litter for M. boaria $(\mathrm{p}<0.019)$, Q. saponaria $(\mathrm{p}<0.005)$ and R. ephedra $(\mathrm{p}<0.009)$ (Table 4; See Table S2 [suppl.] for GLMM summary of each specie). There were no influences of tree cover, seed density and factors interactions on seeds removed (Table 4).

Leaf litter cover showed an influence on seeds removed since the first monitoring, except for $L$. caustica seeds (Fig. 4a). The proportion of seeds removed without leaf litter cover was significantly higher than seeds removed covered by leaf litter for M. boaria (Fig. 4b), Q. saponaria (Fig. 4c) and R. ephedra (Fig. 4d).

\section{Discussion}

Our study reports on the relevance of the removal of seeds dispersed of a sclerophyll forest in Central Chile. It was documented that the invasive alien fauna are removing the seeds and that the absence of leaf litter cover is determinant on the fate of seeds after dispersal (Cintra, 1997).

Table 3. Percentage of visits to the seed removal units of the four trees and shrubs species used in this study by individuals from the species Oryctolagus cuniculus, Rattus sp. and Lycalopex culpaeus, captured by camera trap photographs

\begin{tabular}{lccc}
\hline \multicolumn{1}{c}{ Species } & $\begin{array}{c}\text { Oryctolagus } \\
\text { cuniculus }\end{array}$ & Rattus sp. & Lycalopex culpaeus \\
\hline Lithraea caustica & $30 \%$ & $20 \%$ & $100 \%$ \\
Maytenus boaria & $40 \%$ & $27 \%$ & $0 \%$ \\
Quillaja saponaria & $10 \%$ & $20 \%$ & $0 \%$ \\
Retanilla ephedra & $20 \%$ & $33 \%$ & $0 \%$ \\
\hline Total & $100 \%$ & $100 \%$ & $100 \%$ \\
\hline
\end{tabular}


a)

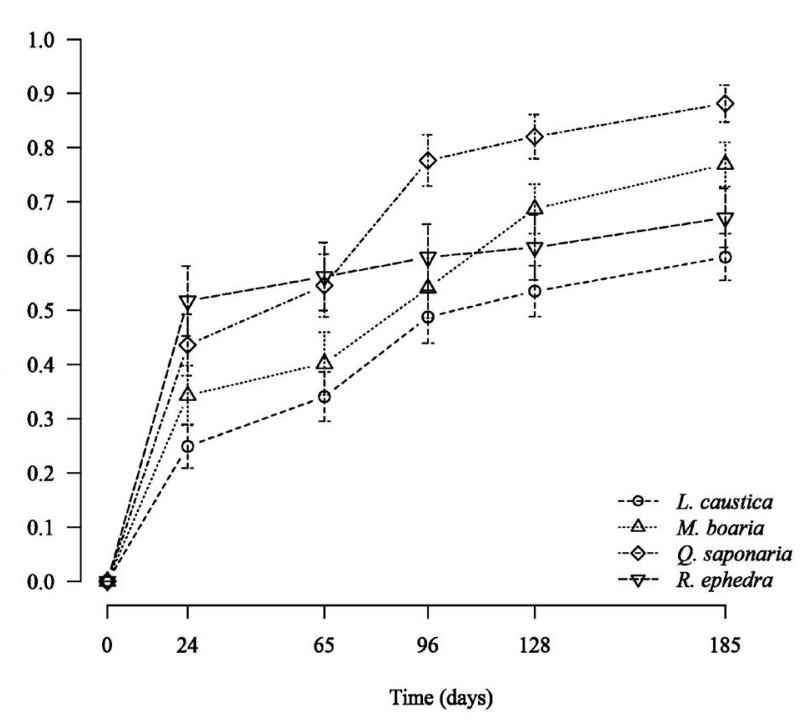

b)

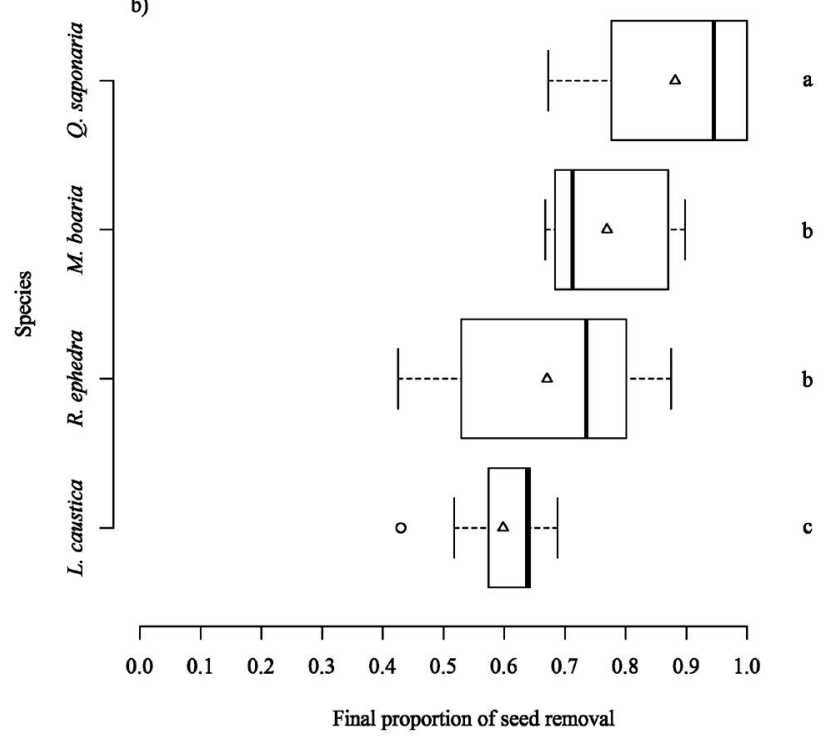

Figure 3. Seeds removed of each specie a) over time and b) at the end of the experiment (day 185). In a) vertical bars on the proportion of seeds removed corresponds to their respective standard error at each date. In b) circle is an outlier and triangles are the mean of the proportion of seeds removed per specie. Different vertical letters $(a, b$ and $c)$ shows statistically significant differences of seeds removed among species $(\mathrm{p}<0.05)$.

At least two of the 10 most dangerous invasive alien mammals in the world (e.g. O. cuniculus and individuals of the genus Rattus; Lowe et al., 2000; European Environment Agency, 2012; Scanes, 2018) were detected removing a large part of the seeds offered. It is known that rodents of the genus Rattus are not hoarding rodents (Meyer \& Butaud, 2009) and that they consume on site small seeds (Lobo et al., 2013). In fact, seed predation by rodents of the genus Rattus was demonstrated by the remains of seeds chewed and nibbled in the SRUs (Fig. S1 [suppl.]) and also by photographs obtained with camera traps. By contrast, it has been suggested that $\mathrm{O} . \mathrm{Cu}$ niculus could act as a seed predator (Martin et al., 2007) and as a primary and secondary seed-dispersing agent (Pakeman et al., 2002; Dellafiore et al., 2006; Castro et al., 2008; Dellafiore et al., 2010). Thus, despite Castro

Table 4. Influence of the factors on the mean proportion of seeds removed of the species studied. The factors shown vertically were tree cover (TC), presence of leaf litter (LL) and seed density (D). Different letters (a, b) show significant differences in the mean proportion of seeds removed between levels of a factor. ${ }^{*} \mathrm{p}<0.05 ; * * \mathrm{p}<0.01 ; * * * \mathrm{p}<0.001$

\begin{tabular}{|c|c|c|c|c|c|}
\hline Factor & Level & Lithraea caustica & Maytenus boaria & Quillaja saponaria & Retanilla ephedra \\
\hline \multirow[t]{3}{*}{ TC: Tree cover } & without & $0.58 \mathrm{a}$ & $0.83 \mathrm{a}$ & $0.86 \mathrm{a}$ & $0.69 \mathrm{a}$ \\
\hline & with & $0.62 \mathrm{a}$ & $0.69 \mathrm{a}$ & $0.82 \mathrm{a}$ & $0.62 \mathrm{a}$ \\
\hline & $p$ & 0.056 & 0.723 & 0.075 & 0.317 \\
\hline \multirow[t]{3}{*}{ LL: Leaf litter cover } & without & $0.58 \mathrm{a}$ & $0.90 \mathrm{a}$ & $0.98 \mathrm{a}$ & $0.85 \mathrm{a}$ \\
\hline & with & $0.62 \mathrm{a}$ & $0.63 \mathrm{~b}$ & $0.70 \mathrm{~b}$ & $0.45 \mathrm{~b}$ \\
\hline & $p$ & 0.182 & $0.019 *$ & $<0.001 * * *$ & $0.009 * *$ \\
\hline \multirow[t]{3}{*}{ D: Seed density } & high & $0.53 \mathrm{a}$ & $0.72 \mathrm{a}$ & $0.85 \mathrm{a}$ & $0.72 \mathrm{a}$ \\
\hline & low & $0.67 \mathrm{a}$ & $0.80 \mathrm{a}$ & $0.85 \mathrm{a}$ & $0.59 \mathrm{a}$ \\
\hline & $p$ & 0.499 & 0.360 & 0.625 & 0.827 \\
\hline \multicolumn{6}{|l|}{ Interactions } \\
\hline TC $\mathrm{x} L L$ & $p$ & 0.179 & 0.924 & 0.515 & 0.629 \\
\hline TC $x$ D & $p$ & 0.154 & 0.108 & 0.069 & 0.846 \\
\hline LL $\times$ D & $p$ & 0.628 & 0.390 & 0.073 & 0.886 \\
\hline TC $x$ LL $x$ D & $p$ & 0.326 & 0.160 & 0.067 & 0.322 \\
\hline
\end{tabular}


a)

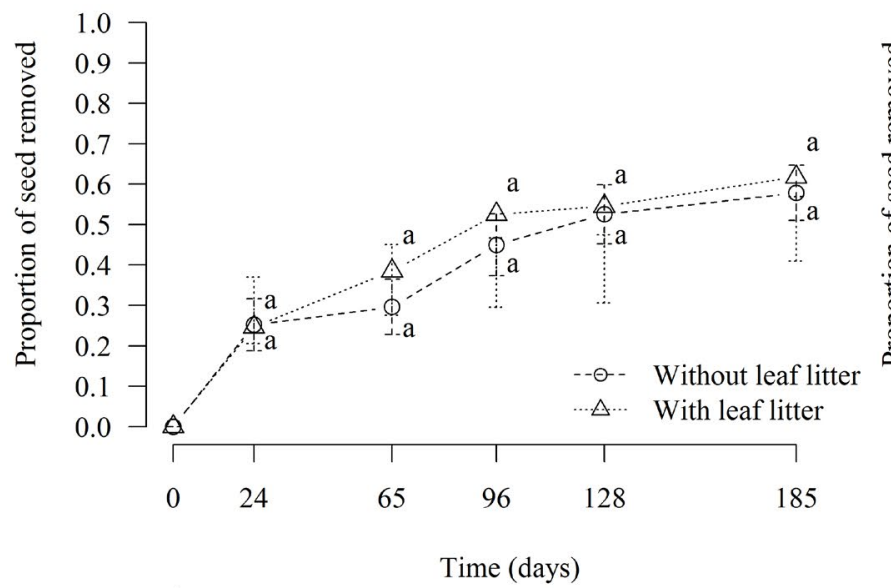

c)

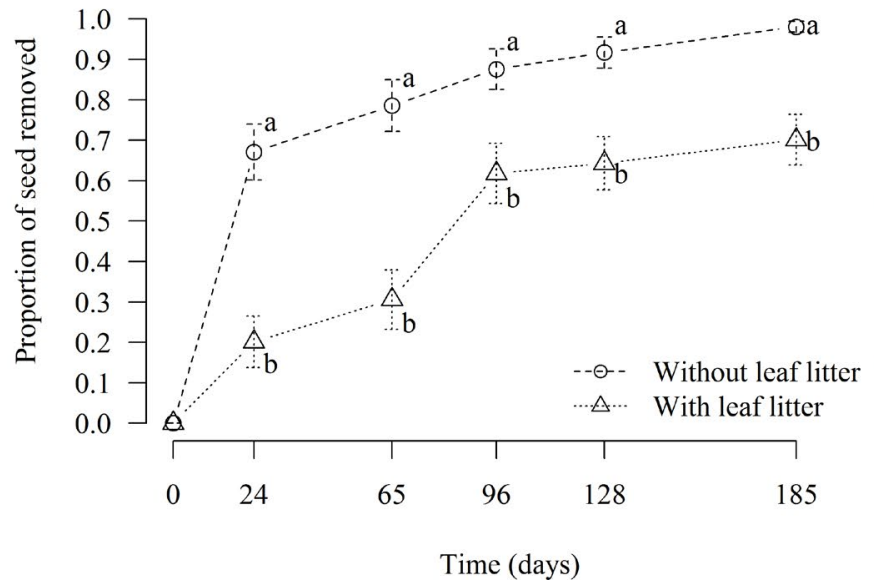

b)
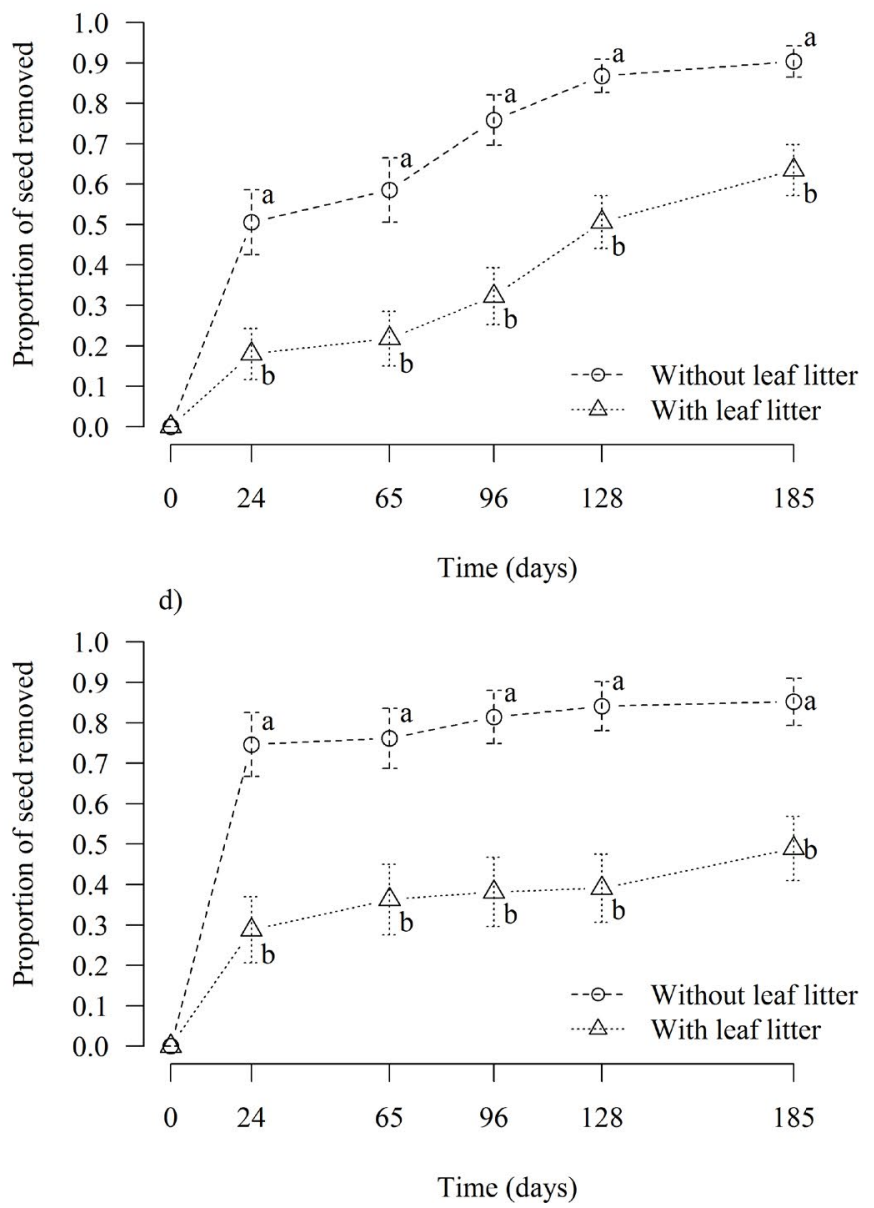

Figure 4. Leaf litter cover influencing seeds removed on a) Lithraea cautica, b) Maytenus boaria, c) Quillaja saponaria and d) Retanilla ephedra. $\mathrm{N}=770$ seeds. Different letters ( $\mathrm{a}, \mathrm{b}$ ) for every evaluation date show significant differences of removal between species $(\mathrm{p}<0.05)$. Vertical bars on the proportions of seeds removed corresponds to their respective standard error at each date.

et al. (2008) suggest that $O$. cuniculus is an effective disperser of $L$. caustica seeds, this and others researches $(e$. g. Reid \& Armesto, 2011) did not have evidence of fecal deposition with the presence of the other three studied seed species. Therefore, we can hypothesize that $O . \mathrm{cu}$ niculus did not consume seeds of M. boaria, R. ephedra and $Q$. saponaria or that $O$. cuniculus destroyed the seeds when it consumed them (i.e. through mastication and digestives process).

Nevertheless, seed removal and predation (as in this case) by these agents has a negative effect on the regeneration of these tree species, the seedling recruitment, the forest structure and the forest dynamics (Simonetti, 1983a; Díaz et al., 1999; Jaksic, 2001; Baldini \& Pancel, 2002; Fernandez \& Sáiz, 2007; Castro et al., 2008; Barceló \& Simonetti, 2020). It is possible to assume that the removal of tree seeds from species in sclerophyll forests (and others vulnerable ecosystems) is affected along the distribution of the invasive alien fauna in Chile (Fernandez \& Sáiz, 2007; Morales et al., 2015; Barceló \& Simonetti, 2020). Hence the importance of controlling invasive aliens fauna for forest conservation and resto- ration (Fernandez \& Sáiz, 2007; Gutiérrez et al., 2007; Morales et al., 2015; Barceló \& Simonetti, 2020), particularly when the forest already has severe problems with the regeneration process (Fuentes et al., 1983; Fuentes et al., 1986; Fuentes \& Muñoz, 1995 Jiménez \& Armesto, 1992; Armesto et al., 1995; Armesto et al., 2007; Schulz et al., 2010) and even more when these are inside protected areas (Barceló \& Simonetti, 2020). Nevertheless, seed removal and seed predation has scarcely been evaluated since the introduction of invasive alien fauna in Chile, such as the case of Rattus rattus (introduced in 1540) or O. cuniculus (mid-1 $18^{\text {th }}$ century; Simonetti, 1983b; Baldini \& Pancel, 2002; Camus et al., 2008; Barceló \& Simonetti, 2020).

L. culpaeus cannot handle the seed precisely with its paws (unlike many herbivorous mammals) (González-Varo et al., 2015) and, therefore, it is suggested that it acts as a seed predator-disperser of $L$. caustica seeds (Castro et al. 1994). However, the dispersal of $L$. caustica seeds by L. culpaeus is neither effective nor efficient for their subsequent germination (Bustamante et al., 1992; León-Lobos \& Arroyo, 1994). 
Contrasting the results obtained by Myster \& Pickett (1993), our results suggest that most of the fauna that remove seeds have a density-independent behavior similar to that found by Hulme \& Hunt (1999), Myster (2003), Marino et al. (2005) and Haught \& Myster (2008). Thus, seed removers did not differentiate between SRUs with high and low seed density possibly due a variety of circumstances that could have acted on the influence of this factor in the removal of dispersed seeds. For example, the consumption of the different densities of seeds offered could also be due to the greater time invested by the fauna that looked for and removed it, possibly for not perceiving danger of being predated. In addition, there could have been a large number of fauna demanding the seeds being studied, removing both densities indiscriminately (Haught \& Myster, 2008). The suggestion by Forget (1993) is also a possibility, in which there may be years of low fruition and thus little food available for granivores. This would lead granivores to consume the greatest amount of seeds offered regardless of the density.

Leaf litter cover affected the decrease in the removal of dispersed seeds in three of the four species studied. These results are consistent with those obtained by other authors (Shaw, 1968; Radvanyi, 1970; Harper, 1977; Schupp, 1988; Willson, 1988; Cintra, 1997; Reed et al., 2004), who suggest that the influence of this factor on seed removal is a pattern that occurs cross-sectionally in forests. Harper (1977) showed that the mere presence of one dead leaf that covers a seed is enough to reduce the possibility of detection by fauna. This means that the presence of leaf litter cover hides the seeds, even when the fauna removes them they make an effort to find these seeds. On the other hand, in addition to hiding the seeds from the fauna, leaf litter may contribute to creating suitable microsites (humidity and temperature) for subsequent seedling germination and recruitment (Cintra, 1997). While a few amount of seeds without leaf litter cover were not removed, these showed to be desiccated (even more the seeds located without tree cover). Instead, seeds with leaf litter seemed well conserved (seeds of all four species) and some of them had started to germinate (e.g. M. boaria and $Q$. saponaria).

Tree cover did not influence seeds removed suggesting the presence of predators in both habitats (Jaksic, 2001). This is supported by evidence (e.g., experiment with camera traps) that the rodents are restricted to dense spaces of cover as a response to the risk of predation in open areas between shrubs (Fuentes et al., 1983; Simonetti, 1983a; Díaz et al., 1999), whereas O. cuniculus lives in both places but they could remove in areas without tree cover (Gálvez-Bravo, 2017).

Under the conditions in which this study was conducted, it is an interesting finding that seed removal of $R$. ephe$d r a, M$. boaria and $Q$. saponaria was severe that suggest possible implications for the recruitment success. Never- theless, the presence of leaf litter prevents seed removal to the alien invasive seed removers and could also generate good microsite conditions for germination and the subsequent establishment of seedlings of the species studied. This suggests that this factor is an indispensable resource to be protected and important to future forest restoration and regeneration plans. Following our findings and others (e. g. Simonetti, 1983a), a restoration management that could be suitable is to exclude individuals trees (the future nurse tree; Root-Bernstein \& Svenning, 2017) to the alien invasive seed removers and seedling predators, with leaf litter inside, allowing good and safe microsite conditions. Thus, there could be multiple clumps (i.e. tree exclusions) that are passively restored in a forest stand that can lead their formation through the process of succession (Newton $\&$ Cantarello, 2015). As regards to alien invasive fauna to alien invasive fauna, only control methods on $O$. cuniculus and rodents of the genus Rattus can be applied (instead eradication; but see Allendorf \& Lundquist, 2003).

Although this study increases the scientific evidence of the removal of dispersed seeds of woody species in a sclerophyll forest in central Chile, this line of research must continue, as it remains an area with many assumptions awaiting evaluation. For example: How much are the seed predation and dispersal of the other tree species in a sclerophyll forest? What are the effects of climate change and site on the generation of flowers and subsequent seed production? What are the best tools for controlling and eradicating invasive alien fauna? Are invasive alien fauna the main problem for sclerophyll forest regeneration? An extensive body of evidence will provide better restoration and conservation tools for this important ecosystem both nationally and internationally.

\section{Acknowledgements}

We thank N. Galindo, R. Herrera, N. Riveros who assisted with the establishment of the experiment in the field, data collection and processing of samples. We are thankful to the Reserva Nacional Río de Los Cipreses and people of the Chilean Forest Service (CONAF). We are especially grateful to Aarón González Castro who assisted with statistic methods. Finally, we want thank to reviewers of this manuscript for their thorough review and their helpful comments.

\section{References}

Alcántara J, Rey P, Sánchez-Lafuente A, Valera F, 2000. Early effects of rodent postdispersal seed predation on the outcome of the plant-seed disperser interaction. Oikos 88(1): 362- 370. https://doi.org/10.1034/j.16000706.2000.880215.x 
Allendorf FW, Lundquist LL, 2003. Introduction: Population Biology, Evolution, and Control of Invasive Species. Conserv Bio 17(1): 24-30. https://doi.org/10.1046/j.1523-1739.2003.02365.x

Armesto JJ, Aravena JC, Villagrán C, Pérez C, Parker G, 1995. Bosques templados de la cordillera de la costa. In: Ecología de los Bosques Nativos de Chile; Armesto J, Villagrán C, Arroyo MK (eds). pp: 109 - 213. Editorial Universitaria, Santiago, Chile.

Armesto J, Arroyo M, Hinojosa L, 2007. The mediterranean environment of Central Chile. In: The physical geography of South America; Veblen T, Young K, Orme A (eds). pp: 184-199. Oxford University Press, New York, USA. https://doi.org/10.1093/ oso/9780195313413.003.0019

Armesto J, Rozzi R, Smith-Ramírez C, Arroyo M, 1998. Conservation Targets in South American Temperate Forests. Science 282(5392): 1271-1272. https://doi. org/10.1126/science.282.5392.1271

Aronson J, Del Pozo A, Ovalle C, Avendaño J, Lavín A, Etienne M, 1998. Land use changes and conflicts in central Chile. In: Landscape Degradation and Biodiversity in Mediterranean Type Ecosystems; Rundel P, Montenegro G, Jaksic F (eds). pp: 155168. Springer-Verlag, New York, USA. https://doi. org/10.1007/978-3-662-03543-6_9

Arroyo M, Uslar P, 1993. Breeding systems in a temperate mediterranean-type climate montane sclerophyllous forest in central Chile. Bot J Linn Soc 111(1): 83-102. https://doi.org/10.1006/boj1.1993.1008

Arroyo M, Armesto J, Squeo F, Gutiérrez J, 1993. Global change: The flora and vegetation of Chile. In: Earth-System Responses to Global Change: Contrasts between North and South America; Mooney H, Fuentes E, Kronberg B (eds). pp: 239-264. Academic Press, California, USA.

Baldini A, Pancel L, 2002. Agentes de daño en el bosque nativo. Editorial Universitaria, Santiago, Chile. 408 pp.

Barceló M., Simonetti JA, 2020. Rattus rattus, a potential threat to the endangered tree Gomortega keule in the Maulino forest of Chile. New Zeal J Bot, 1-6. https:// doi.org/10.1080/0028825X.2020.1799041

Bates D, Maechler M, Bolker B, Walker S, 2015. Fitting Linear Mixed-Effects Models Using lme4. J Stat Softw 67(1): 1-48. https://doi.org/10.18637/jss.v067.i01

Bustamante R., Simonetti JA, Mella J, 1992. Are foxes legitimate and efficient seed dispersers? A field test. Acta Oecol 13(2): 203-208.

Bustamante R, 1995. Depredación de semillas en bosques templados de Chile. In: Ecología de los Bosques Nativos de Chile; Armesto J, Villagrán C, Arroyo M (eds). pp: 265-278. Editorial Universitaria, Santiago, Chile.

Bustamante R., Vásquez R, 1995. Granivoría en Cryptocarya alba (Mol.) Looser (Lauraceae): los efectos del tipo de hábitat y la densidad de semillas. Rev Chil Hist Nat 68(1): 117-122.

Camus P, Castro S, Jaksic F, 2008. El conejo europeo en Chile: Historia de una invasión biológica. Historia 41(2): 305-339. https://doi.org/10.4067/S071771942008000200001

Castro S, Silva S, Meserve P, Gutiérrez J, Contreras L, Jaksic F, 1994. Frugivoría y dispersión de semillas de pimiento (Schinus molle) por el zorro culpeo (Pseudalopex culpaeus) en el Parque Nacional Fray Jorge (IV Región, Chile). Rev Chil Hist Nat 67(1): 169-176.

Castro S, Bozinovic F, Jaksic F, 2008, Ecological efficiency and legitimacy in seed dispersal of an endemic shrub (Lithraea caustica) by the European rabbit (Oryctolagus cuniculus) in central Chile. J Arid Environ 72(7): 1164-1173. https://doi.org/10.1016/j.jaridenv.2007.12.012

Cintra R, 1997. Leaf litter effects on seed and seedling predation of the palm Astrocaryum murumuru and the legume tree Dipteryx micrantha in Amazonian forest. J Trop Ecol 13(5): 709-725. https://doi.org/10.1017/ S0266467400010889

Connell J, 1971. On the role of natural enemies in preventing competitive exclusion in some marine animals and in rain forests. In: Dynamics of population. Centre for Agriculture Publishing and Documentation; den Boer P, Gradwell G (eds). pp: 298-312. UHR Books, Maine, USA.

Cowling R, Rundel P, Lamont B, Arroyo M, Arianoutsou M, 1996. Plant diversity in mediterranean-climate regions. Trends in Ecol Evol 11(9): 352-360. https://doi. org/10.1016/0169-5347(96)10044-6

Dalling J, 2002. Ecología de semillas. In: Ecología y conservación de Bosques Neotropicales; Guariguata M, Kattan G (eds). pp: 345-375. Libro Universitario Regional, Cartago, Costa Rica.

Dellafiore C, Muñoz S, Gallego J, 2006. Rabbits (Oryctolagus cuniculus) as dispersers of Retama monosperma (L.) Bois seeds in a coastal dune system. Ecoscience 13(1): 5-10. https://doi.org/10.2980/1195-6860(2006)13[5:ROCADO]2.0.CO;2

Dellafiore C, Gallego J, Muñoz S, 2010. The rabbit (Oryctolagus cuniculus) as a seed disperser in a coastal dune system. Plant Ecol 206(2): 251-261. https://doi. org/10.1007/s11258-009-9639-7

Del Pozo A, Fuentes E, Hajek E, Molina J, 1989. Zonación microclimática por efecto de los manchones de arbustos en el matorral de Chile central. Rev Chil Hist Nat 62(1): 85-94.

Díaz I, Papic C, Armesto J, 1999. An assessment of post-dispersal seed predation in temperate rain forest fragments in Chiloe Island, Chile. Oikos 87(2): 223238. https://doi.org/10.2307/3546738

Dudenhöffer J H, Pufal G, Roscher C, \& Klein AM, 2016. Plant density can increase invertebrate 
postdispersal seed predation in an experimental grassland community. Ecol Evol 6(11): 3796-3807. https:// doi.org/10.1002/ece3.2039

Elizalde R, 1970. La sobrevivencia de Chile. El Escudo, Impresores-Editores Ltda., Servicio Agrícola y Ganadero, Ministerio de Agricultura, Santiago, Chile. 492 pp.

European Environment Agency, 2012. The impacts of invasive alien species in Europe. Technical report nro.16/2012. Work document for international use.

Fernández A, Sáiz F, 2007. The european rabbit (Oryctolagus cuniculus L.) as seed disperser of the invasive opium poppy (Papaver somniferum L.) in Robinson Crusoe Island, Chile. Mastozoo Neotro 14(1): 19-27

Forget P, 1992. Seed removal and seed fate in Gustavia superba (Lecythidaceae). Biotropica 24(3): 408-414. https://doi.org/10.2307/2388611

Forget P, 1993. Post-dispersal predation and scatterhoarding of Dipteryx panamensis (Papilionaceae) seeds by rodents in Panama. Oecologia 94(2): 255-261. https:// doi.org/10.1007/BF00341325

Fox J, Weisberg S, 2019. An $\{\mathrm{R}\}$ Companion to Applied Regression, Third Edition. Thousand Oaks CA: Sage. https://socialsciences.mcmaster.ca/jfox/Books/Companion/

Fuentes ER, Hoffmann AJ, Poiani A, Alliende MC, 1986. Vegetation change in large clearings: Patterns in the Chilean matorral. Oecologia 68, 358-366. https://doi. org/10.1007/BF01036739

Fuentes ER, Jaksic F, Simonetti JA, 1983. European rabbits versus native rodents in Central Chile: effects on shrub seedlings. Oecologia 58(3): 411-414. https:// doi.org/10.1007/BF00385244

Fuentes ER, Muñoz M, 1995. The human role in changing landscapes in central Chile: Implications for intercontinental comparisons. In: Ecology and Biogeography of Mediterranean Ecosystems in Chile, California, and Australia; Arroyo MTK, Zedler PH, Fox MD (eds). pp: 401-407. Springer-Verlag, New York, USA. https://doi.org/10.1007/978-1-4612-2490-7_17

Gálvez-Bravo L, 2017. Conejo - Oryctolagus cuniculus. En: Enciclopedia Virtual de los Vertebrados Españoles. Salvador, A., Barja, I. (Eds.). Museo Nacional de Ciencias Naturales, Madrid. 35 pp.

García D, Obeso J, Martínez I, 2005. Rodent seed predation promotes differential recruitment among bird-dispersed trees in temperate secondary forests. Oecologia 144(3): 435-446. https://doi.org/10.1007/s00442-0050103-7

González-Varo J, Fedriani J, López-Bao J, Guitián J, Suárez-Esteban A, 2015. Frugivoría y dispersión de semillas por mamíferos carnívoros: rasgos funcionales. Ecosistemas 24(3): 43-50. https://doi.org/10.7818/ ECOS.2015.24-3.07

Gutiérrez J, Holmgren M, Manrique R, Squeo F, 2007. Reduced herbivore pressure under rainy ENSO con- ditions could facilitate dryland reforestation. J Arid Environ 68(2): 322-330. https://doi.org/10.1016/j.jaridenv.2006.05.011

Grubb P, 1977. The maintenance of species-richness in plant communities: the importance of the regeneration niche. Biol Rev 52(1): 107-145. https://doi.org/10.1111/j.1469-185X.1977.tb01347.x

Harper J, 1977. Population biology of plants. Academic Press, London, UK. 892 pp.

Haught J, Myster R, 2008. Effects of Species, Density, Season and Prairie-type on Post-dispersal Seed Removal in Oklahoma. Am Midl Nat 159(2): 482-488. https://doi.org/10.1674/0003-0031(2008)159[482:E OSDSA]2.0.CO;2

Herrera C, Jordano P, Lopez-Soria L, Amat J, 1994. Recruitment of a mast-fruiting, bird ispersed tree: Bridging frugivore activity and seedling establishment. Ecol Monogr 64(3): 315-344. https://doi. org $/ 10.2307 / 2937165$

Hobbs R, Richardson M, Davis W, 1995. Mediterranean-type ecosystems. Opportunities and constrains for studying the function of biodiversity. In: Mediterranean-type ecosystems. The function of biodiversity; Davis G, Richardson D. (eds). pp: 1-42. Springer-Verlag, California, USA. https://doi.org/10.1007/978-3642-78881-9 1

Hulme P, Hunt M, 1999. Rodent post-dispersal seed predation in deciduous woodland: predator response to absolute and relative abundance of prey. J Anim Ecol 68(2): 417-428. https://doi.org/10.1046/j.13652656.1999.00294.x

Jaksic F, 2001. Spatiotemporal variation patterns of plants and animals in San Carlos de Apoquindo, central Chile. Rev Chil Hist Nat 74(2): 477-502. https://doi. org/10.4067/S0716-078X2001000200021

Janzen D, 1970. Herbivores and the number of tree species in tropical forest. Am Nat 104(940): 501-528. https://doi.org/10.1086/282687

Jaña R, 2012. Animal seed dispersal and its consequences for plant recruitment. Doctoral thesis. University of Canterbury, Christchurch, New Zeland.

Jiménez H, Armesto J, 1992. Importance of the soil seed bank of disturbed sites in Chilean matorral in early secondary succession. Journal of Vegetation Science 3(5): 579-586. https://doi.org/10.2307/3235824

Lenth RV, 2016. Least-Squares Means: The R Package lsmeans. J Stat Softw 69(1): 1-33. https://doi. org/10.18637/jss.v069.i01

León-Lobos P, Arroyo M, 1994. Germinación de semilla de Lithraea caustica (Mol.) H. et A. (Anacardiacea) dispersadas por Pseudalopex sp. (Canidae) en el bosque esclerófilo de Chile central. Rev Chil Hist Nat 67(1): 59-64.

Lobo N, Green D, Millar J, 2013. Effects of seed quality and abundance on the foraging behavior of deer 
mice. J Mammal 94(6): 1449-1459. https://doi.org/10.1644/12-MAMM-A-295.1

Lowe S, Browne M, Boudjelas S, De Poorter M, 2000. 100 of the World's Worst Invasive Alien Species A selection from the Global Invasive Species Specialist Group (ISSG) a specialist group of the species survival commission (SSC) of the World Conservation Union (IUCN). Auckland, New Zealand. 12 pp.

Luebert F, Pliscoff P, 2017. Sinopsis Bioclimática y Vegetacional de Chile. Segunda Edición. Editorial Universitaria, Santiago, Chile. 381 pp.

Marino P, Westeman P, Pinkert C, van der Werf W, 2005. Influence of seed density and aggregation on post dispersal weed seed predation in cereal fields. Agr Ecosyst Environ 106(1): 17- 25. https://doi.org/10.1016/j.agee.2004.07.001

Martin G, Twigg L, Zampichelli L, 2007. Seasonal changes in the diet of the European rabbit (Oryctolagus cuniculus) from three different Mediterranean habitats in south-western Australia. Wildlife Res 34(1): 25-42. https://doi.org/10.1071/WR06044

Medan D, Aagesen L, 1995. Comparative flower and fruit structure in Colletieae (Rhamnaceae). Bot Jahrb Syst 117(4): 531-564.

Medan D, Arce ME, 1999. Reproductive biology of the Andean-disjunct genus Retanilla (Rhamnaceae). Plant Syst Evol 218(3-4): 281-298 https://doi.org/10.1007/ BF01089232

Meyer JY, Butaud JF, 2009. The impacts of rats on the endangered native flora of French Polynesia (Pacific Islands): drivers of plant extinction or coup de grâce species? Biol Invasions 11(7):1569-1585. https://doi. org/10.1007/s10530-008-9407-y

Montenegro G, Avila G, Aljaro E, Osorio R, Gómez M, 1989. Chile. In: Plant Pheno-morphological Studies in Mediterranean Type Ecosystems. G Orshan (ed). pp: 347-387. Springer Netherlands, Dordrecht, Netherlands. https://doi.org/10.1007/978-94-009-3107-7_5

Morales N, Becerra P, Arellano E, Gilabert B, 2015. Effect of large and small herbivores on seed and seedling survival of Beilschmiedia miersii in central Chile. Bosque 36(1): 127-132. https://doi.org/10.4067/ S0717-92002015000100014

Morales-Paredes C, Valdivia C, Sade S, 2015. Frugivory by native (Lycalopex spp.) and allochthonous (Canis lupus familiaris) canids reduces the seed germination of litre (Lithrea caustica) in central Chile. Bosque 36(3): 481-486. https://doi.org/10.4067/S071792002015000300014

Myers N, Mittermeier RA, Mittermeier CG, da Fonseca GAB, Kent J, 2000. Biodiversity hotspots for conservation priorities. Nature 403(6772): 853-858. https:// doi.org/10.1038/35002501

Myster R, 2003. Effects of species, density, patch-type, and season on post-dispersal seed predation in a Puer- to Rican Pasture. Biotropica 35(4): 542- 546. https:// doi.org/10.1111/j.1744-7429.2003.tb00610.x

Myster R, Pickett S, 1993. Effects of litter, distance, density and vegetation patch type on postdispersal tree seed predation in old fields. Oikos 66(3): 381-388. https://doi.org/10.2307/3544932

Naveh Z, Wittaker R, 1979. Structural and floristic diversity of shrublands and woodlands in Northern Israel and other Mediterranean areas. Vegetatio 41(3): 171190. https://doi.org/10.1007/BF00052445

Newton AC, Cantarello E, 2015. Restoration of forest resilience: An achievable goal? New Forest 46(5-6): 645-668. https://doi.org/10.1007/s11056-015-9489-1

Pakeman R., Digneffe G, Small J, 2002. Ecological correlates of endozoochory by herbivores. Funct Ecol 16(3): 296-304. https://doi.org/10.1046/j.13652435.2002.00625.x

Radvanyi A, 1970. Small mammals and regeneration of white spruce forests in western Alberta. Ecology 51(6): 1102-1105. https://doi.org/10.2307/1933641

R Core Team, 2019. R: A language and environment for statistical computing. R Foundation for Statistical Computing, Vienna, Austria. https://www.R-project. org/

Reed A, Kaufman G, Kaufman D, 2004. Effect of plant litter on seed predation in three prairie types. Am Midl Nat 155(2): 278-285. https://doi.org/10.1674/0003-00 31(2006)155[278:EOPLOS]2.0.CO;2

Reid S, Armesto J, 2011. Interaction dynamics of avian frugivores and plants in Chilean Mediterranean shrubland. J Arid Environ 75(3): 221-230. https://doi.org/10.1016/j.jaridenv.2010.10.002

Root-Bernstein M., Svenning J-C, 2017. Restoring connectivity between fragmented woodlands in Chile with a reintroduced mobile link species. Perspect Ecol Conser 15(4): 292-299. https://doi.org/10.1016/j.pecon.2017.09.001

Rundel P, 1998. Landscape disturbance in mediterranean-type ecosystems: An overview. In: Landscape Disturbance and Biodiversity in Mediterranean-Type Ecosystems; Rundel P, Montenegro G, Jaksic M (eds). pp: 3-22. Springer-Verlag, California, USA. https:// doi.org/10.1007/978-3-662-03543-6_1

Salazar A, Baldi G, Hirota M, Syktus J, McAlpine $C, 2015$. Land use and land cover change impacts on the regional climate of non-Amazonian South America: A review. Global Planet Change 128: 103-119https://doi.org/10.1016/j.gloplacha.2015. 02.009

Scanes C, 2018. Invasive Species. In: Animal and human society; Scanes C, Toukhsati S (eds). pp: 413-426. Academic Press, London, UK. https://doi.org/10.1016/ B978-0-12-805247-1.00024-1

Schulz J, Cayuela L, Echeverría C, Salas J, Rey M, 2010. Monitoring land cover change of the dryland 
forest landscape of Central Chile (1975-2008). Appl Geogr 30(3): 436-447. https://doi.org/10.1016/j.apgeog.2009.12.003

Schulz J, Cayuela L, Rey-Benayas J, Schroder B, 2011. Factors influencing vegetation cover change in Mediterranean Central Chile (1975-2008). Appl Veg Sci 14(4): 571-582. https://doi.org/10.1111/j.1654109X.2011.01135.x

Schupp E, 1988. Factors affecting post-dispersal seed survival in a tropical forest. Oecología 76(4): 525-530. https://doi.org/10.1007/BF00397864

Shaw M, 1968. Factors affecting the regeneration of sessile oak (Quercus petraea) in North Wales. II. Acorn losses and germination under field conditions. J Ecol 56(3): 647-666. https://doi.org/10.2307/2258097

Simonetti JA, 1983a. Effect of goats upon native rodents and European rabbits in the Chilean matorral. Rev Chil Hist Nat 56(1): 27-30.

Simonetti JA, 1983b. Occurrence of the black rat (Rattus rattus) in central Chile. Mammalia 47(1): 131-132.
Uribe J, Cabrera R, de la Fuente A, Paneque M, 2012. Atlas Bioclimático de Chile. Departamento de Ciencias Ambientales y Recursos Naturales Renovables, Universidad de Chile, Santiago, Chile. 232 pp.

Velazco SJE, Blum CT, Hoffmann PM, 2018. Germination and seedlings development of the threatened species Quillaja brasiliensis. CERNE, 24(2), 90-97. https://doi.org/10.1590/01047760201824022530

Yu F, Shi X, Wei K, \& Wang D, 2015. Leaf litter affects the survival and predation rates for large and smallPinusseeds in the Qinling Mountains, China. Isr J Ecol Evol 61(3-4): 162-168. https://doi.org/10.1080/15659 801.2016.1176689

Westfall P, Tobias R, Rom D, Wolfinger R, Hochberg Y, 1999. Multiple Comparisons and Multiple Tests Using the SAS System. Cary, NC: SAS Institute Inc.

Willson M, 1988. Spatial heterogeneity of post-dispersal survivorship of Queensland rainforest seeds. Aust J Ecol 13(2): 137-146. https://doi.org/10.1111/j.1442-9993.1988.tb00963.x 